\title{
Cash Balance Pension Plans: Good News or Bad News?
}

Arundhati Rao, (E-mail: arao@moac.morgan.edu), Morgan State University Leslee Higgins, (E-mail: higginsl@gasou.edu ), Georgia Southern University

Sandra Taylor, Lakeland College

\begin{abstract}
Modification of defined benefit plans and conversion of defined contribution plans into Cash Balance Pension Plans (CBPs) has attracted a lot of attention recently. A comparison of the three plans and an examination of 10 companies reveal a significant financial incentive in favor of CBPS. The "good news" for a younger employee is level accrual of benefits and plan portability, and for stockholders, a smaller impact on net income. CBPs bear "bad news" for older and/or less mobile employees and the stockholders when the plan assets perform poorly.
\end{abstract}

\section{Introduction}

$\varnothing$ ob seekers view stock options and employment benefits (e.g., health care and pension benefits) as adding value to their current compensation (Rao, 1996). While most companies offer stock option plans to only a few key employees, they usually offer employment benefits to all full-time employees. In the United States, until the late 1980s, most companies offered defined benefit pension plans. Over the years the administration of these plans has become expensive and time-consuming, mainly due to the growing number of rules and regulations imposed by the government. It was not surprising that in the late 1980s and early 1990s, many companies switched from the traditional defined benefit pension plan to a defined contribution pension plan, which is easier to maintain. In a defined contribution plan, the company is only responsible for making the pre-defined contribution to the pension plan, not its subsequent performance. Over the past few years several large companies have been adopting a new type of pension plan called Cash Balance Pension Plans (CBPs), and steadily abandoning the traditional defined benefit as well as defined contribution plans. Technically, a CBP is a defined benefit plan, but contains some characteristics of defined contribution plans. While the CBP has been in existence since $1985^{2}$, there is very little awareness of this plan among the public in general. The United States Congress and the Internal Revenue Services Department are still debating the legality of some of the aspects of this new type of pension plan (McCarthy, 2000). Only recently accounting texts (Keiso et. al., 2000, p. 1152) have devoted a small paragraph to the introduction of CBPs.

This descriptive paper compares three types of pension plans: defined benefit, defined contribution, and CBPs and discusses the relative advantages and disadvantages of each of these plans to the major stakeholders. The paper addresses the question, "Are Cash Balance Pension Plans Good News or Bad News?" for the two major stakeholders: the employees and the employers/stockholders.

\section{Comparison among the Three Types of Plans}

This section describes the three types of pension plans: defined benefit, defined contribution, and CBPs and compares them to each other. The objective here is to gain a better understanding of CBPs and to determine whether or not this type of plan is better than the defined benefit plan or the defined contribution plans for the stakeholders. The chart presented in the appendix summarizes the characteristics of the three types of plans.

Readers with comments or questions are encouraged to contact the authors via email. 


\section{Defined Benefit Pension Plan}

The main characteristics of a defined benefit pension plan are:

1. A participant's benefit is derived from a formula that depends on factors such as salary and years of service;

2. An actuary must calculate the contributions required to fund the plan benefits based on actuarial liability, plan assets, and funding method adopted by the plan sponsor;

3. $\quad$ Only the employer contributes to the plan;

4. The employer is responsible for the investment risk;

5. Pension benefit payment is in the form of an annuity.

The sponsor (typically the employer) of the plan is responsible for investing the plan assets or must appoint a plan manager to do the same. Over funded plans and/or higher returns on the plan assets will reduce pension expense, and in some cases may result in reporting a pension income. Over funding may also reduce future employer contributions. On the other hand, under funded plans and/or lower returns on the plan will require higher contributions in the future.

A company is not required to separate the plan assets for individual participants. Most defined benefit plans pay monthly benefits calculated by a benefit formula, but other optional forms of payment such as lump sum or joint and survivor annuity are also available. In the event of a plan failure the Pension Benefit Guarantee Corporation (PBGC), a governmental agency, provides a guarantee of the accrued benefits up to a certain amount to the employees. The employer pays PBGC a risk-weighted premium each year for this protection; this premium is an additional cash expense for the employer.

\section{Defined Contribution Plan}

The main characteristics of a defined contribution pension plan are:

1. The contribution formula (determined by the employer) defines the contribution but not the benefit to be paid out at retirement;

2. The contribution formula is usually a percentage of the current salary, and the benefit at retirement is a function of the contributions and investment earnings;

3. Usually the employer matches the employee's contribution to the plan up to a certain limit;

4. $\quad$ The employee bears the risk of investment returns;

5. Payment usually is a lump-sum amount at retirement, however the employee may opt for an annuity.

Since the contributions are defined and the employer does not guarantee the performance of the pension assets, the accounting for defined contribution plans is very easy. Typically the employer appoints a plan manager to manage the assets. Unlike defined benefit plans, the PBGC does not guarantee defined contribution plans. However this is not a problem as a defined contribution plan is always fully funded.

\section{Cash Balance Pension Plans (CBPs)}

The main characteristics of a CBP are:

1. Just like a defined contribution plan, the amount of contributions is pre-determined by the employer (usually a percentage of current salary);

2. The employer guarantees a rate of return such as a fixed percent or a percent tied to a known market rate such as the US 30-year treasury rate;

3. Like the defined benefit plans, the employer bears the risk of returns;

4. $\quad$ Only the employer contributes to the CBP;

5. At termination or retirement, a participant typically receives a lump sum distribution. 
A CBP has some characteristics of both defined benefit and defined contribution plans. If the CBP earns a return lower than the promised rate of return the employer makes up the difference, resulting in an additional cash expense when the market is not doing well. However, unlike a defined benefit plan, if the CBP earns more than the promised rate of return, the employer can take the excess returns out of the pension plan and put it into the company's coffers. Since the rate of return is fairly low, one can expect the plan assets to yield higher than expected returns resulting in pension income for the employer. Each participant has a (hypothetical) separate account in a cash balance plan. Since the CBP is a type of defined benefit pension plan, the PBGC guarantee benefits. Finally, for all three types of pension plans, the contributions to the plan and earnings of the plan assets are tax-free until withdrawal.

\section{Cash Balance Pension Plans - Good News or Bad News?}

Many sponsors of traditional defined benefit plans feel that their employees do not appreciate the value of those plans. One reason is that under a traditional defined benefit plan the benefit is an annuity, not an account balance, i.e., a lump-sum figure. However, a defined benefit plan has better delivery efficiency than a defined contribution plan because, on average, each dollar contributed by a plan sponsor under a defined benefit plan delivers more value to the employee than under a defined contribution plan. The main reason for the higher delivery efficiency under a defined benefit plan is that the sponsor is responsible for investing the plan assets. However, the reality is that defined benefit plans are very expensive to fund and manage. Also employees usually have to work for the same employer for a relatively long time to first become "vested" and then to enjoy the "true" benefits of a defined benefit plan. In recent years, although some employees have changed jobs voluntarily, many employees have changed jobs involuntarily. The latter case is an unfortunate outcome of mergers, takeovers and downsizing. Under such circumstances, portability of pension benefits becomes a very important issue.

CBPs emerged 15 years ago, with a goal of improving employee appreciation while maintaining the delivery efficiency of a defined benefit plan. In addition to defined contributions, the accrual (i.e., earnings) pattern is more level (guaranteed returns), so retirement benefits accrue faster and more evenly throughout the employee's service than under a traditional defined benefit pension plan. CBPs favor employees with less tenure and greater mobility. The plans are also very easy to understand. This is certainly "good news" for the employees.

Many employers who offer defined benefit plans do not wish to continue to assume the administrative responsibilities associated with plan management. CBPs respond to this desire in more than one way. The CBPs are not only simple to administer, but also less expensive. This is the "good news" for the employer. If the plan assets produce returns greater than the plan guarantees, the employer keeps the excess. This results in additional revenue for the employer which stockholders view as "good news." During prosperous times, CBPs will be a very attractive feature to stockholders.

For employees, the "bad news" is that the guaranteed rate of return is low (usually one or two percent above the prime rate) as compared to the returns offered by the stock markets. During prosperous times, employees do not share in the excess returns that their pension assets earn. Defined benefit plans are more attractive to older employees with a longer tenure as well as several younger employees who do not wish to change jobs or are not mobile, mainly because the plan benefits are not transferable. It is only if employees are mobile, that CBPs are the better option.

\section{CBP Adoption Issues}

So who stands to lose when a company adopts a CBP? If a company with a defined benefit plan modifies it into a CBP, older employees closer to retirement lose their higher projected benefits. In the past couple of years, modification of defined benefit plans and conversion of defined contribution plans into CBPs has received a lot of negative publicity. IBM Corp, as an example, forced the modification on all their employees, regardless of age and tenure, and also failed to communicate the details of the modification process to its employees. After severe negative publicity, pressure from employees, and threats of numerous lawsuits from individuals as well as labor unions, IBM back-tracked and gave the older employees a choice between continuing with the defined benefit plan 
or adopting the new CBP at a more favorable rate (McCarthy 1999). However, IBM has not yet managed to bring closure to this issue.

To mimic the benefit accrual pattern of a traditional defined benefit plan, some employers adopted an ageweighted formula that gives more credits to older employees or have included grandfather provisions to phase in the new plan formula while protecting anticipated benefits of employees who are close to retirement age. When there is a modification or conversion, and it is not optional and/or poorly communicated, it causes a sense of betrayal, uncertainly, and turmoil among the employees. All of these emotions may adversely affect the employees' morale and productivity, in turn, eventually hurt the bottom line. This is definitely "bad news" for everyone.

\section{Some Empirical Evidence}

When IBM announced their intention to modify their defined benefit plans to CBPs, several irate employees decided to become proactive and educate themselves about their employer's unilateral decision. Some employees created a message board on Yahoo's Message Board. Lynda French, a veteran IBM employee of 22 years, decided to use the internet to fight for employees' right (Washington, 2000). Even after IBM reconsidered and changed the terms of the conversion, French has continued to update the website ${ }^{3}$ for other people who are or will be facing similar problems. As of January 2001, there are 368 companies listed on the website. A search on Yahoo Finance ${ }^{4}$ indicated that 105 are listed on the New York Stock Exchange, 13 are listed on the NASDAQ, and four are listed on the American Stock Exchange. Two hundred and forty six companies are foreign companies and/or not listed on any US stock market. All 368 companies listed on French's website have already adopted a $\mathrm{CBP}$ or intend to do so in the near future.

Of the 105 companies listed on the New York Stock Exchange, 10 were selected at random for this study. The companies selected for this study represent manufacturing, retail and service firms, and range from small to large in terms of number of employees and also total assets and revenues. We examined the SEC filings - Form 10$\mathrm{K}$ for the year 1999 (filed in early 2000) that was available on the Internet ${ }^{5}$. The focus of our examination was the Management Discussion and Analysis and the Notes to the Financial Statement referring to pension benefits, in particular the number of employees and the funded status of the Defined Benefit Plan. Table One presents the number of employees in each of these companies.

\begin{tabular}{|lc|}
\hline \multicolumn{2}{|c|}{ Table 1 } \\
\hline Company Name & Number of Employees \\
\hline Kroger Food Company & 305,000 \\
Verizon (Bell Atlantic + GTE) & 260,000 \\
SBC Communications & 204,530 \\
Lucent Technologies & 126,000 \\
Goodyear Tire \& Rubber Company & 108,561 \\
Aetna Life Insurance & 35,000 \\
Service Corporation International & 30,693 \\
Ashland & 25,000 \\
KeyCorp & 24,568 \\
Laboratory Corporation of America & 17,960 \\
\hline
\end{tabular}

Four of the companies studied, Verizon (Bell Atlantic and GTE prior to the merger), SBC Communications, Lucent Technologies and Aetna Life Insurance had already adopted the CBPs. Based on the information available in the $10-\mathrm{K}$, each of these companies offered different types of grandfather provisions in the conversion process. For example, Bell Atlantic grandfathered employees with at least 15 years of service, while Lucent Technologies gave some choice to employees hired prior to October 1, 1996, but employees hired after this date were automatically enrolled into the new CBP. SBC Communications' final date of conversion is June 1, 2002.

The other six companies neither have a CBP in place nor have mentioned their intentions of converting to a CBP in their 10-K. It is possible that these companies are still working through the conversion process. Information of this nature is more likely to be discussed by the media long before it is disclosed and/or discussed in an annual report. 


\begin{tabular}{|c|c|c|}
\hline \multicolumn{3}{|c|}{ Table 2} \\
\hline Company Name & & Inded Status* \\
\hline Verizon (Bell Atlantic + GTE) ** & & $5,145,000,000$ \\
\hline SBC Communications & & $, 273,000,000$ \\
\hline Lucent Technologies & & $3,666,000,000$ \\
\hline Aetna Life Insurance & & $447,400,000$ \\
\hline Goodyear Tire \& Rubber Company & & $300,800,000$ \\
\hline KeyCorp & & $282,000,000$ \\
\hline Kroger Food Company & & $265,000,000$ \\
\hline Service Corporation International & $\$$ & $1,983,000$ \\
\hline Laboratory Corporation of America & & $(200,000)$ \\
\hline Ashland & & $(89,000,000)$ \\
\hline \multicolumn{3}{|c|}{$\begin{array}{l}\text { * Funded Status }=\text { Plan Assets }- \text { Projected Benefit Obligation } \\
* * \text { As per the } 199910-\mathrm{K} \text { 's, prior to the merger, Bell Atlantic and } \\
\text { GTE's funded stauts was } \$ 15,064 \text { and } \$ 11,081 \text { million respectively. }\end{array}$} \\
\hline
\end{tabular}

Prior to the conversion, all 10 companies offered some type of defined benefit plan to most of the employees who qualified to participate in a pension plan. Some companies also offered defined contribution plans to some of their employees. What is of particular interest in this paper is the financial impact on the employer when a CBP is adopted. Table Two presents the funded status of the companies' defined benefit pension plans.

Only two of the 10 companies are currently under funded. Funded status was calculated based on Projected Benefit Obligation. When companies switch to CBPs the funded status, for employees not covered under the grandfather provision, should be calculated based on Accumulated Benefit Obligation, i.e., the present value of the vested benefits. This will dramatically strengthen the funded status of the eight over funded companies and may even change the status of the under funded companies, Laboratory Corporation of America and Ashland to an over funded status. This is "good news" for the employers and stockholders.

Depending on how the conversions (and agreements with employees) are worked out, these companies may be in a position to make the over funded plans a cash cow. If the company buys an annuity for the Accumulated Benefit Obligation as of the date the plan is adopted, the company may be in a position to cash in on the excess, which in many cases may amount to millions of dollars. For example, in 1999 when IBM's conversion took place, the company recorded a one-time pension income of $\$ 600$ million, positively impacting the net income number that year. The conversion to CBPs also means smaller (cash) pension expenses and less administrative hassles in the future; once again "good news" for the employers and stockholders. Again using IBM as an example, the company reports that it expects to save approximately $\$ 200$ million each year after the conversion.

When companies look to trim their budget, an expense that is scrutinized very closely is the labor expense. On January 24, 2001, Lucent Technologies announced it would lay off 10,000 employees - the company claims this will save them $\$ 2$ billion per year. On January 29, 2001, Chrysler-Diamler Corporation announced it would lay off 26,000 employees - an inevitable decision to just continue to stay in business! The financial incentives that could result from a conversion to CBPs, in the short run as well as in the long run, are just too large to be ignored.

\section{Conclusion}

Changes in the economy and market place have caused employers to reconsider retirement benefits offered to employees. Many companies believe that CBPs are here to stay. The "good news" for employees is that CBPs plans are portable, always fully funded, and offers a rate of return guaranteed by the employer. The "bad news" is the rate of return is usually low. The "good news" for employers is that the accounting for CBPs is very easy and less expensive than defined benefit plans. In addition, employers enjoy the excess returns on the plan assets if they are higher than the guaranteed rate. Only when the market performs very poorly is it "bad news" for the employer; the company will have an additional cash outlay in such periods.

A study of four companies that have adopted and six companies that intend to adopt the CBPs reveals a significant financial incentive in favor of the conversion. Depending on how the conversions are worked out, these companies may be in a position to make the over funded defined benefit plan (that existed prior to the conversion) into a cash cow. Employers can avoid a majority of the bad publicity that CBPs have suffered recently through effective communication and education. Pensions are still an important benefit offered by employers. Employees offered the new CBPs might need to rethink how they intend to finance their retirement. 


\section{Suggestions for Future Research}

Cash balance pension plans are here to stay. There are no empirical studies that have addressed the true impact of CBPs on employees and stockholders. So far various anecdotal evidence suggests that CBPs are unfavorable to older employees but favorable to younger employees and stockholders. It will be interesting to study the financial health of companies that elected to adopt versus those that did not adopt the CBPs. Another question that needs to be addressed is how much did the companies profit when a defined benefit plan was modified into a $\mathrm{CBP}$ and how much are they now saving on pension expense?

\section{References}

1. Keiso, D., J. Weygandt, and T. Warfield, "Intermediate Accounting”, $10^{\text {th }}$ edition, John Wiley \& Sons, Inc., p. 1152, 2000.

2. McCarthy, E., "Staying off the Cover of Time," Journal of Accountancy, vol. 189, issue 2, p. 31, 4p, 4c, February 2000

3. Rao, Arundhati, "Impact of Funded Status of Defined Benefit Pension Plans on the Quality of Earnings" Ph.D. dissertation, University of Cincinnati, Ohio, December1996.

4. Washington, L., "The Online Pension Activist: Lynda French Uses the Web to Fight for Employees' Rights," Money, Vol. 29, issue 4, p. 142, April 2000.

\footnotetext{
${ }^{1}$ The authors wish to thank Carey Curtis, Betty Horn and Allen Schick for their insightful comments and helpful suggestions.

${ }^{2}$ In 1985 Bank of America was the first company in the United States to offer a Cash Balance Pension Plan to its employees.

${ }^{3}$ The web site created and maintained by Lynda French is: http://www.cashpension.com

${ }^{4}$ http://finance.yahoo.com

${ }^{5}$ Annual reports of 2,200 publicly traded companies are available on http://www.reportgallery.com
} 